\title{
The Toponymy of Remembered Childhood
}

\section{W. F. H. Nicolaisen}

I find it difficult to remember whether it was in the course of studying and teaching folktales or while reading autobiographical reminiscences that I first discovered that the past is not just a time but also a place. Perhaps this new awareness was the hardly surprising result of both these influences. Far be it from me to labor under the illusion that this, for me, novel way of looking at the past was a new perspective so revolutionary that it was likely never to have been thought of before.

But even if born out ignorance on my part rather than out of insight, this realization was nevertheless for me personally, when it happened, startling enough in its innovativeness to allow me to see a phenomenon which had fascinated me for a good while in a surprising new light. There had been one part of me probing for many years the structure and function of time in the folktale, as well as in narrative in general, regarding it as the sole basis for the creation of the past through narration and exploring the various relationships of narrative time, narration time, narrated and non-narrated time, and recounted time to historical time and to each other. ${ }^{1}$

There had been another part of me exploring systematically the kind of evidence place names are in the investigation of linguistic history, in the establishment of relative chronological stratification, in the recapturing of the sense of place which had motivated the namers of places, and, perhaps most fundamentally, in the delineation of the changing contents of the various names in question, in addition to the tracing of their etymological origins. ${ }^{2}$

There had been these two mes, interrogating narratives and surveying names for almost a scholar's lifetime as if these were two very separate and almost imcompatible exercises, and realizing only quite recently that homo narrans and homo nominans are, indeed, the same people responding to the same intellectual stimuli, essential and existential for the survival of homo sapiens - narrating and naming, telling stories and 
structuring the world around us through the imposition of names ("Names and Narratives").

And yet, in all these activities, in all this searching and researching, and even after the recognized coalescence of narrare and nominare, I remained seduced by that ubiquitous incantatory opening phrase "Once upon a time...," which seemed to suggest that one creates the past through the narration of true chunks of time, and time only. Admittedly, I had dabbled in the scrutiny of spatial arrangements in the folktale, and it had occurred to me occasionally that the function of names in autobiographical writings might be worth examining one day, but what had eluded me all that time and what has only now become capable of articulation for me is the stunning realization that, for both the teller of folktales and the purveyor of personal experience narratives in the autobiographical mode, the past is as much a spatial concept as a temporal one.

For the needs of folktale scholarship I have therefore suggested the formulaic opening "Once upon a place..." as a parallel to the familiar "Once upon a time..." to express the equally strong pre-occupation of traditional storytellers with narrated space, as with narrated time, especially in the symbolic act of the journey. And where is this spatial past in which the world of the folktale is located? I have tried elsewhere to show that frequently encountered allusions and orientations in the märchen indicate that, for example, it lies beyond the beyond, in a wild part of the country where strangers seldom come, on a high hill in a lonely wood, or, more generally, simply in a certain place. Its location is remote and inaccessible but can yet be experienced in homely, familiar terms. It is other but not strange and therefore recognizable; paradoxically, it is on both sides of high mountains and of the deep river. The world of the folktale is thus the unmappable, acartographic place where the ahistoric past is created through narration. In keeping with the nature of the folktale it is, of course, also usually in unnamed space, and if names of countries or other geographical features do occur, they function metonymically to symbolize the exotic, the distant, or the very bizarre.

While the geographical space of folktales has consequently very little scope to offer to the name scholar, the places remembered and recorded in the autobiographical accounts of chilhood are, in contrast, eminently namable and, therefore, frequently named or recalled as named and are, as a result, ready grist to the onomatologist's mill, especially if

\section{Nicolaisen}


that mill happens to be of the literary kind. Presumably one can squabble over the degree of fictitiousness with which childhood reminiscences, even the seemingly most objective ones, are embued; there can be little doubt, however, that such reflections, several decades and a bundle of experience later, reveal, filtered through the benign prism of hindsight, not only the personal deployment of subjective time but also the reconstructed localizations of subjective space - a space named to such an extent that, on the one hand, it persuades through its designated locatability, and, on the other, condenses experience through toponymic encapsulation. While reminiscing writers are apparently making the spatial components of their early years accessible to the public, what really happens is that the private contents of named places remains uncommunicated, particularly when readers have, in response, not much contents to bring to the names displayed; that is, they don't know them at all or know them only vaguely.

Let me illustrate what I mean by some examples from a volume which triggered this essay, a recent anthology entitled $A$ Scottish Childhood, to which about seventy well-known Scots contributed various kinds of childhood recollections. The oldest of the contributors, the novelist and travel and science fiction writer Naomi Mitchison, after comparing the two houses of her childhood in urban Edinburgh and in rural Cloan, Argyllshire, describes in predominantly spatial terms her grandfather's Edinburgh residence:

10 Randolph Crescent towered five storeys up in front, but, as it was built on the edge of a cliff above the Water of Leith, dropped down for countless storeys on the west side, past all of which one must climb to get to the gardens. This was a distinctly alarming process.... All this was below the kitchens and the wine cellar, far below Grandpa's study where gentlemen were allowed to smoke, the dining-room, and above it the great double drawing-room and 'boudoir' where there was a singularly horrid picture on an easel of a Boy looking good with long ringlets and a hockey stick. . . . Above them again were the best bedrooms, and the narrower stairs to our room above. All has been remodelled inside into unrecognizability.... (Kamm and Lean 2$)$ 
This is one-half of a childhood remembered, indeed conceived in distinctly spatial terms. Even today still acknowledged as a "good address" by the citizens of the Scottish capital, 10 Randolph Crescent is recollected as an inside experience in unmistakable vertical relationships, spatial as well as social and more stratified than a mere upstairsdownstairs juxtaposition, each level from "best bedrooms" to cellars, and ultimately to the gardens on the river-bank, assessed in their familial, aesthetic and physical ascriptions: A childhood re-visualized as a traversing of these vertical strata with the help of stairs. This is 10 Randolph Crescent as it was about eighty years ago, cast in a kind of idealized reality but its recognizability now obliterated, its reality now obscured and distorted by unthinking, falsifying remodelling.

There is an almost ecstatic outward extension to Mrs. Mitchison's recollected inward space, a horizontal exterior to the vertical interior, named in terms of some of Edinburgh's best known landmarks:

I was taken for walks, my hand held firmly, but I was allowed to run in Prince's Street Gardens or in the Randolph Crescent gardens that sloped steeply to the Water of Leith and St. Bernard's Well repaired by one of my forebears but whose water I was wisely not allowed to drink. (Kamm and Lean 3)

In this private appropriation of named public places, she accommodates her nurturing childhood beliefs and traditions:

I often hoped I would see a would-be suicide floating down from the Dean Bridge, parachuted by a petticoat as the story had it. Edinburgh pavements were particularly appropriate for the lines and squares ritual with their huge granite sets. I avoided the lines as, presumably, most right thinking people do. Yet there must be some who actually step on the lines. It would be interesting to know with what other abnormality this is correlated. (Kamm and Lean 3)

Nicolaisen 
In contrast to Naomi Mitchison's upper-class Edinburgh reminiscences, Jack House's spatial focus of his Glasgow childhood, though eminently namable and mappable for him and certain knowledgeable Glaswegians, will elicit little recognition from those not familiar with the urban landscape of Scotland's Second City:

... the pavement, which we all preferred to the Field, ... was in front of the four closes which made up the odd side of Kennyhill Square. A close, in case you don't know, is an entry to a tenement building. On each floor there were two facing flats, eight in all since it was a three-storey tenement. The numbers were 1, 3,5 and 7 Kennyhill Square, looking straight at the entrance to the bowling green which separated the odd and even sides. (Kamm and Lean 17)

Like 10 Randolph Crescent, 7 Kennyhill Square is, to all intents and purposes, a postal address, the number distinguishing it from other addresses in Randolph Crescent or Kennyhill Square, the street name from other streets in Glasgow or Edinburgh. For Jack House and Naomi Mitchison, however, the numerical and onomastic precision with which they pinpoint their childhood space - who says anything of time here-is not for the convenience of some postman, now long gone, but is a fundamental act of named remembrance: "Once upon a place I was a child." Reminding us that these places were in Glasgow and Edinburgh, respectively, they toponymically assert their own non-interchangeability, their personal uniqueness, and embody an attempt at communicating their essentially private contents. Where Naomi Mitchison reports nostalgically on the gentility of her grandparents' residence. Jack House wistfully remembers the pavement in Kennyhill Square for his first love affair; what was Edinburgh's burgeois Prince's Street Gardens to the girl Naomi is epitomized in Glasgow's working class Alexandra Park for the boy Jack, public ludic space away from the narrower confines of home - of 10 Randolph Crescent and 7 Kennyhill Square, that is - and yet somehow incorporated in a wider concept of homeliness of the place that once was childhood.

Several contributors to the anthology effectively use place names to establish contrasts between city and country, working year and vacation, 
school and play, at home and abroad, war and peace, England and Scotland; but to explore these contrasts in detail would require a paper in itself. Many of these accounts include journeys, mainly by train, not only initiated and terminated at named stations but often also punctuated by the names of intermediate stops. Walter Coutts, for example, remembers:

At Easter, we used to go [to St. Fillans] by train, through a wonderful succession of nowdefunct stations-Gleneagles, Tullibardine, Highlandman, Muthil, Crieff, Comrie, Dalchonzie, and so to base. (Kamm and Lean 44)

Surely, these place names, almost all of them of Gaelic origin and therefore lexically meaningless to the writer and his family, are enumerated here not only to indicate the route taken and to shed a grownup's tear over the loss of a railway line so important to childhood travel, but also as a string of toponymic pearls, a succession of spellings and sounds associated with a loss of childhood itself and of its irrecoverable pleasures - placenames evocative of a loss of innocence, fossils not only linguistically but also generationally, reminders of a journey taken and completed.

The singer Moira Anderson also re-visions her childhood vacations not just in terms of space occupied and explored, but more particularly through the recollected reverberating toponymy of travel:

My parents, my two brothers, my sisters and I spent our holidays with my uncle Tom in Brora, Sutherland, and from there we explored Caithness to the north and Easter Ross to the south. We left Kirkintilloch in the early morning to travel to Glasgow's Buchanan Street Station where the north-bound train awaited us. (Kamm and Lean 169)

And then the inquisitive eyes of the travelers encountered a sequence of places mostly intimated through their named stations, a toponymic litany of the journeying child (and today's adult, for that matter): Stirling, Perth, Dunkeld, Pitlochry, Blair Atholl, Kingussie,

\section{Nicolaisen}


Aviemore, Inverness, Lairg, Golspie, Dunrobin, and, the destination, Brora: ". . . when we finally tumbled out of our carriage we had been travelling for more than eight hours" (Kamm and Lean 170).

This is a list of names marking a desirable progression from south to north, from Lowland to Highland, from work and school to leisure and play-names which gradually increase in promise and hope and anticipation, the further removed from Kirkintilloch the travelers journey and the closer they approach Brora, names that are stages in a journey of expectation and of maturation, names that not only pace movement but also space the testimony of childish delight, names as symbols of the spatial accommodation of youthful adventure.

Naturally, these are only a few telling examples of the toponymy of remembered childhood as offered in the anthology in question; there are dozens more like them in that collection. Instead of selecting several more of them to make my point even more strongly, it seems to be preferable to turn, for my closing comments, to autobiographies of three famous Scots of an earlier generation, as a kind of control to ensure that the pieces chosen for the anthology are not to any biasing extent colored by the predilections of its editors. The eminent Scots I have in mind are R.H. Bruce Lockhart, the Rev. James L. Dow, and John Buchan. This is Lockhart writing in the mid-thirties:

I was born in Anstruther in the East Neuk of the Kingdom of Fife. The house in which I first raised my voice to the four winds was the Waid Academy, a small grammar school of which my father was then headmaster.... The East Neuk is that portion of the county of Fife which lies east of a perpendicular line drawn from St. Andrews to Largo. Anstruther itself bears the proud title of an ancient royal borough.... The town, which has a picturesque harbour, is lashed by the cold North Sea. ... (5-6)

Book I of Lockhart's My Scottish Youth, from which these statements have been extracted, is significantly called "Son of the Soil." Chapter 1 of James Dow's reminiscences No Better Than I Should Be bears the title "A Paisley Lad": 
Grandfather and Grandmother lived in a cottage at the foot of Taylor's Wynd in Dundee. . .. Ours was the last close in Greenlaw Avenue in Paisley and over the garden wall was a sizable piece of vacant ground which we called the Park, and where we played our games. (14-15)

Both Lockhart and Dow are obviously name and place conscious, the former mostly in terms of the map and of his childhood's coordinates on it, the latitudes and longitudes of youth, so to speak, the latter predominantly in the distancing separation of grandparental and parental home and of walled-in domesticity on the one hand ("the last close in Greenlaw Avenue") and playful exuberance and competition on the other ("the Park").

I have deliberately left John Buchan's Memory Hold-the-Door till last, for in the opening statements of his first chapter whose placeoriented title is "Wood, Water and Hill," this accomplished Scottish thinker, statesman, and novelist says in felicitous prose what this interpreter could not even approach to express in similarly persuasive and sensitive language. Before I allow him the last word on my behalf, however, in the knowledge that the artist is always one step ahead of the scholar, permit me a brief onomastic summary in my own much less adequate words. What this brief essay has confirmed, I hope, is that the past, in the rearview mirror of autobiographical writing, is at least as much a place as a time and that, contrary to the treatment of past unmappable space in folktales, adult rememberers of childhood feel constrained to name the focused, structured, private, and public places in which they were children, or perhaps rather in which they re-envision, re-create, themselves as children. Thus the toponymy of remembered childhood, consisting of real names fictionalized in the imaginative process of remembering, is a valuable, externalizing, and, to us scholars, revealing, non-etymological landscape of symbols, a specialized onomastic field representing location, juxtaposition, journeying, shelter, generational interior and exterior space - playful, adventurous, dangerous, promising space, space of expectation and fulfillment - a constellation of named places whose major content it is now to have once accommodated children. 
And here is John Buchan:

As a child I must have differed in other things besides sanctity from the good Bernard of Clairvaux, who, we are told, could walk all day by the Lake of Geneva and never see the lake. My earliest recollections are not of myself, but of my environment. It is only reflection that fits my small presence into this picture. When a few months old I was brought by my parents to a little grey manse on the Fife coast. It was a square, stone house standing in a big garden, with a railway behind it, and in front, across a muddy byroad, a linoleum factory, a coal pit and a rope-walk, with a bleaching-works somewhere in the rear.... (13)

Where, then, is that toponymy of remembered childhood? Now we know-it is somewhere between the railway in front and the bleachingworks behind. No wonder, we sometimes have trouble finding it.

\section{State University of New York at Binghamton}

\section{Notes}

1. This is a revised version of a paper read at the annual conference of the American Name Society in San Francisco (Dec. 27-30, 1987).

2. See Nicolaisen, "Time in Folk-Narrative"; "Concepts of Time and Space"; "Structure of Narrated Time."

3. In addition to several articles, see especially Nicolaisen, Scottish Place-Names.

\section{Works Cited}

Buchan, John. Memory Hold-The-Door. London: Hodder and Stoughton, 1940.

Dow, James L. No Better Than I Should Be. London: Hutchinson, 1975. Kamm, Antony, and Anne Lean, eds. A Scottish Childhood: 70 Famous Scots Remember. Glasgow: Collins, 1985.

Lockhart, R.H. Bruce. My Scottish Youth. London: Putnam, 1937. 
-.. "Concepts of Time and Space in Irish Folktales." Celtic Folklore and Christianity: Studies in Memory of William H. Heist. Ed. Patrick K. Ford. Santa Barbara: McNally and Lofton, 1983. 150-158.

.... "Names and Narratives." Journal of American Folklore 97(1984): 259272.

-.-. "Once upon a place, or where is the world of the folktale?" Sichtweisen der Volkskunde. Eds. Albrecht Lehmann and Andreas Kuntz. Berlin-Hamburg: Dietrich Reimer, 1988. 359-366.

-.-. Scottish Place-Names: Their Study and Significance. London: B.T. Batsford, 1976.

-.-. "Space in Folk Narrative." Folklore on Two Continents-Essays in Honor of Linda Dégh. Ed. Nikolas Burlakoff and Carl Lindahl. Bloomington, IN: Trickster Press, 1980. 14-18.

-.-. "The Structure of Narrated Time in the Folktale." Le conte pourquoi? comment? Paris: Editions du Centre National de la Recherche Scientifique, 1984. 417-436.

\title{
CALL FOR PAPERS
}

\section{IDAHO-WYOMING}

Idaho and Wyoming will celebrate centennials in 1990. A special issue of Names in the spring will commemorate that occasion. Papers on any aspect of naming--placenames in the state, Indian names, literary names, personal names--will be considered. Deadline: September 15, 1989. Direct inquiries or send copies to the editor.

\author{
Prof. Thomas J. Gasque \\ Dept. of English \\ University of South Dakota \\ Vermillion, SD 57069 \\ (605) 677-5229
}

